\title{
Are we tribalistic? Demarcation disputes in Vuwani Vhembe District
}

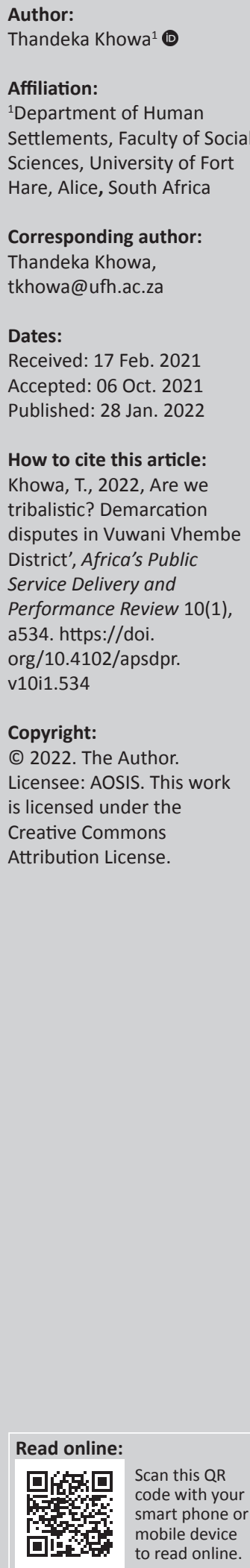

Background: Vuwani community expressed their rejection of the municipal boundary demarcations which resulted in the formation of the Collins Chabane Municipality made-up of parts of Vuwani community and Malamulele community. A number of media reports had alluded that much of what is presented as demarcation disputes is largely fueled by tribalism (Baloyi 2018).

Aim: Using relevant literature, this study aimed at examining claims of tribalism in Vuwani demarcation disputes. In so doing the study examines the claims of tribalism as a catalyst in the demarcation disputes in Vuwani.

Setting: The area of study is Vuwani Vhembe District in South Africa. However lessons learnt are not limited to South Africa but contributes to the body of knowledge on demarcations in Africa and worldwide.

Methods: A qualitative approach was adopted using in-depth and focus group discussion analysed through Territorial and Inclusion theories.

Results: The findings revealed that clustering Vuwani demarcation disputes as being merely tribalistic is a narrow and dismissive approach to the amalgamation disputes in Vuwani. The findings further revealed the contributing factors to the demarcation disputes in Vuwani such as lack of adherence to good governance principle, lack of transparency etc. have led to many misconceptions which fueled the ongoing demarcation disputes.

Conclusion: Adherence to good governance principles and policies is essential in redrawing of the spatial boundaries. Land, especially rural land is a sensitive commodity in Africa because of the effects of colonialism and apartheid. Thus, redrawing of spatial boundaries need to be carried out with extreme caution.

Keywords: municipal demarcation; Vuwani Vhembe District; tribalism; good governance; rural land.

\section{Introduction and background}

The determination of municipal boundaries in South Africa is viewed as an important starting point in the transformation and development of the country. Thus, local government is of paramount importance in ensuring that transformation and development is carried through as this sphere of government is in direct contact with the people of South Africa, especially the previously disadvantaged, mainly the rural communities. The Constitution of the Republic of South Africa, No. 105 of 1996 Section 152 directs, outlines and further stipulates the envisaged objects of a new democratic South Africa. Thus, it further places much emphasis on the restructuring and redrawing of the South African boundaries. The Constitution acknowledges that redrawing of municipal and provincial boundaries is the starting point in ensuring a democratic South Africa and addressing all the spatial injustice and inequality of the Apartheid government (Bekink 2006). Re-demarcation of municipal boundaries is aimed at ensuring that municipalities are sizable, feasible and are held accountable to the needs of their people.

The drawing of a new municipal boundary is a sensitive aspect in South Africa because of the fact that the period of colonialism and apartheid left immense challenges on the boundaries of the country (Nabudere 2000). Thus, the Constitution of the Republic of South Africa, in its bid to ensure transformation, expressed the need for the formation of a structure whose sole mandate is to redraw and readjust the spatial setting of the country. This resulted to the 
establishment of the Municipal Demarcation Board (MDB), whose role as stipulated by the Constitution of the Republic of South Africa of 1996, it that the MDB is a standalone body tasked with re-demarcating municipal and provincial boundaries of South Africa adhering to good governance principles. The Municipal Demarcation Act No. 108 of 1996 further stipulates the roles of the MDB supported by Chapter Seven of the Constitution of the Republic of South Africa No. 108 of 1996. The roles of the MDB as stipulated by the act are as follows:

- It acts as an advisor in issues provided for by the act in terms of demarcations;

- To demarcate provincial and municipal boundaries in South Africa in line with the principles of the act.

- To consider the act and Chapter Seven of the Constitution in terms of demarcation boundaries of South Africa.

The MDB, however, in line with good governance principles, is required to uphold transparency, by informing the country of said planned demarcation by publishing it in the Provincial Gazette. Thus, if there is any rejection, a window period of 30 days is available for the public to submit a written objection. Based on the objection, the MDB may contemplate withdrawal of demarcation, vary, or confirm demarcation, by publishing its final decision with reasons in the Provincial Gazette.

\section{Determination of boundaries and the resistance to re-demarcations in South Africa}

Boundary delimitation is defined as the drawing of boundaries, mainly of electoral states, countries or municipalities. Donaldson and Williams 2008 states that drawing of electoral boundaries is used to prevent unbalance of population across districts. A number of legislations have been adopted by the South African government to ensure smooth transition and delamination of municipal and provincial boundaries. The adoption of policies such as the Cross-boundaries Municipalities Act of 2000, the Municipalities Repeals and Related Act of 2005 have however fell short as demarcations are still largely opposed by citizens and communities of South Africa. Demarcation has faced a high rate of resistance from communities (Cameron 1999). In some areas, local communities, such as Khutsong, were totally opposed to demarcation, and this opposition resulted in boycotts and damage to property.

The following section highlights examples of some of the demarcation disputes.

\section{The case of Ethekwini Municipality}

\section{Nature of dispute}

In 1999/2000, the demarcation process was heavily contested mainly by the traditional authority who believed that demarcation was nothing but a strategy to strip traditional leaders of their powers. Pillay (1999) states that traditional leaders were very concerned about losing their power to the local government, which became a pressing issue and stifled the procedure of demarcation. The relevance of traditional leadership has been questioned as community members were torn apart as some people felt that traditional leadership were dominant in the new democratic South Africa, while others opposed this notion. The independence of the MDB was questioned, as traditional leaders felt that demarcation was a political strategy of the leading party to gain votes in areas in which they had little authority.

\section{Case of Bushbuckridge}

\section{Nature of dispute}

In 1994, the former Transvaal province was dismantled and divided into four provinces. The area from Bushbuckridge to Hazyview was to be included in Limpopo province. This decision was undertaken because most of the Bushbuckridge area had been part of three separate Bantustans (Gazankulu, Lebowa, and KaNgwane) (Bushbuckridge Local Municipality 2009).

The bigger sector of Bushbuckridge falls in parts of Gazankulu, which was incorporated into the Limpopo province. Therefore, the MDB felt that it was appropriate to include Bushbuckridge into the Limpopo province. The communities of Bushbuckridge who demanded that they should be included under the Mpumalanga province rejected this move, by arguing that their needs would not be catered for in the Limpopo province as they are situated $300 \mathrm{~km}$ from the capital city of Polokwane. Service delivery was the main dispute that resonated in the rejection of the amalgamation. This resulted in riots and further disputes in communities as a form of expressing their rejection of the amalgamation.

\section{Intervention and outcome}

In the midst of riots, four people lost their lives, and school and government property were destroyed (Niehaus 2005). The riots costed the economy 40 million rands (Griggs 1998; Narsiah \& Maharaj 1999). Eventually, in December 2005, the government decided to establish Bushbuckridge as a cross boundary municipality meaning that it would be serviced by both the Limpopo and Mpumalanga province. With the dissolution of cross boundary municipalities in South Africa, a decision was taken to incorporate Bushbuckridge back into Mpumalanga province.

\section{The case of Matatiele}

\section{Nature of dispute}

In 2006, the Matatiele Municipality was moved from the Sisonke District Municipality in KwaZulu-Natal and incorporated into the Alfred Nzo District Municipality situated in the Eastern Cape province. This has been argued as a political scheme initiated by the government to serve the ruling parties' interests in downsizing the control of opposing parties in Matatiele (Nketo 2018). 


\section{Intervention and outcome}

Demarcation of Matatiele is still an issue, as the African National Congress (ANC) government took a decision that Matatiele was to join the Eastern Cape and not KwaZuluNatal. According to Mandla Galo (African Independent Congress):

[T] he ANC had promised to resolve the Matatiele issue, but nothing had materialized, they must go back to their national working committee to reject that decision which was taken by the ANC against the will of the people. (Nketo 2018:1)

To date the government is still in negotiations with the people of Matatiele who are still opposing the demarcation.

\section{The case of Khutsong}

\section{Nature of dispute}

Also in 2006, the entire Merafong City Local Municipality, which included Khutsong, was to be transferred from West Rand District Municipality in Gauteng province to the Southern District Municipality in the North West province. The residents of Khutsong objected to the transfer from wealthy Gauteng to the poorer North West, resulting in protests and riot demonstrations, which saw the destruction of government property, bombing of ANC official homes and eventually the closing down of the municipality.

\section{Intervention and outcome}

The conflict in Khutsong lasted over a period of three years, but the matter was later resolved with the help of the High Court. Khutsong was re-incorporated into the Gauteng province with the amendment of section 1 and section 74(2) of Chapter 2 (the Bill of Rights).

\section{The case of Vuwani}

In July 2015, the MDB announced that it envisaged the amalgamation of Malamulela, Tshikonelo, Mulenzhe, Piet-boy, and Khakhanwa (which is under Thulamela Municipality) and Masia, Mashau, Vyeboom, Tshino, Davhana, Tshimbupfe, Ramukhuba, Masakona (which is under Makhado Municipality) to form one municipality (SABC 2016). The municipal authority went ahead with the envisaged amalgamation in 2015, stating that consultations were held with all stakeholders involved and affected by the demarcation. The MDB further expressed that all stakeholders were and board with the then proposed demarcation thus the amalgamation was passed and formed. In 2016, however, the country saw an uprising of communities affected by this demarcation opposing the planned operationalisation of the amalgamation. This resulted in the inevitable conflict between municipal authorities, the MDB, traditional authorities and the community members of Vuwani. The Vuwani community embarked upon demonstrations as they expressed their rejection of the amalgamation, resulting in looting, burning, and destruction of government and private property.

\section{Tribalism in demarcations}

Tribalism has been linked with demarcation disputes, arguments that communities reject proposed demarcations mainly underlying causes being service delivery and tribal issues (Kanyane, Adonis \& Rule 2021).

The Limpopo province is unique in South Africa as it is home to a number of ethnic groups that is the baPedi, xiTsonga, vhaVenda, baSotho, Indians, white people and mixed race people. Municipal boundaries 243 in Limpopo province are inclusive of two or more ethnic groups as is the case in the Vhembe district (Buhlungu et al. 2007). Three ethnic groups dominate in Vuwani, that is, the vhaVhenda, xiTsonga and baPedi. Thus, for this particular study the focus was on these ethnic groups and the assumptions that tribalism amongst these ethnic groups is the catalyst to the ongoing demarcation disputes in Vuwani. Mathoho (2013) argues that in situations where more than one ethnic group are affiliated within one municipality, tribalism comes into play. South Africa is a diverse country, which is home to many ethnic groups. Thus, tribalism becomes a domain and is highly influenced by the scarcity of resources as ethnic groups compete for resources. Khowa (2020) argues that such claims are baseless as Limpopo communities and its people, despite the diversity, have lived together in harmony for many years.

Moloi (2016) warns of a new form of pandemic that he argues could have a far worse implication than that of apartheid. Moloi argues that South Africa is a country that is good in dressing wounds rather than healing them, stating that the false notion that post 1994 South Africa was a united nation without properly healing under the Truth and Reconciliation commission had more harm as the wounds of the past were not addressed but covered. Thus, he argues that the turmoil we are experiencing as a country stem from this behaviour of covering up issues instead of healing them. Tribalism seems to be sneaking in as history depicts that each tribe has its own connection and cultural identity that rejects other groups, which thus creates tension and leads to conflicts (Moloi 2016:1).

The policies and legislations of the apartheid government in terms of the Group Areas Act 41 of 1950 (Group Areas Act 41,1950$)$ can be argued as having great contributions to the issues of tribalism. The Group Areas Act facilitated the spatial segregation process thus moving black people to Homelands and Bantustans thereby facilitating the 'own management for own' areas principle and the pass law system. This system not only divided people based on race but also further divided the people of South Africa in terms of ethnicity and tribe thus initiating a system of division amongst black people.

This is visible when looking at the landscape of the country as certain provinces are home to specific ethnic groups. For example, KwaZulu-Natal is home to the Zulu tribe, whilst the Eastern Cape province is home to the Xhosa tribe, Free State province being home to the Sotho/Tswana tribe. This in 
turn has created conflicts between different tribes as they seek to dominate each other and compete for power.

These apartheid policies and / or legislations further weakened the structure of traditional leadership in the country. As per the Group Areas Act 41 of 1950, the sole mandate by the apartheid government was to relinquish the then colonial government of administration and financial burden of black areas - Homelands and Bantustans - thus not developing and not providing services to black people. The traditional leaders were thus entrusted with running and ruling the Homelands. However, their powers relied mainly upon, and were to a greater deal influenced by, the colonial government (Rugege 2002). This resulted in some traditional leaders serving the mandate and becoming spies to the colonial government. Thus, the structure of traditional leaders was tempered resulting in the people not trusting the loyalties and traditional authorities (Republic of South Africa 1950).

\section{Territorial theory}

Territorial theory has been adopted in this study as it helps to explain the issues of tribalism. Margaret Moore, a prominent scholar of this theory argues that territoriality is viewed as a major cause of conflict.

To expand this discussion the research looks into the territorial and inclusion theories guiding the study. Territoriality is viewed as the major cause of conflict. According to Hensel (1998), territoriality is an approach that is commonly used to study the conflicts and disagreements amongst people and over some type of controversial issues. He further argues that resolving these issues rests mainly on how the oppositions decide to handle and sort their conflict, and whether or not it may lead to serious conflicts. Many issues can result in conflicts and lead to more serious issues. The perspectives of territoriality argue that boundary issues are more noticeable and are most likely to lead to war or riots because of the value they have within specific areas of jurisdiction (Vasquez 1999, cited in Hensel 1998).

Territoriality is defined as non-verbal communication amongst people who share the same space, thus possessing ownership. These people share common things such as language, culture, ethics, religion, and moralities. Soja (1971) further argues that territoriality can be viewed as a behaviour that people residing in a spatial sphere identify with, and share common influences. In the context of the nature of this study, understanding the theory of territoriality is important, to gain insight of the historical formation of marked boundaries, which can be otherwise viewed as territories marked according to certain criteria.

A territory can be deemed valuable if perhaps it has material things to which people feel entitled; and because of this, territories have been exposed to disputes as all people want to have a hold (Goertz \& Diehl 1992, cited in Hensel 1998). Resources play a significant role in the territorial disputes of land in Africa remaining the most valuable asset and the major cause of conflict. The entity or religious groups just like land play a major role in territoriality. Contextually and most importantly, territories have tangible benefits that contribute to the power dynamics of that certain area as well as the security levels in their regard, and the autonomous state of being rooted in that territory (Murphy 1990). In the case of the study area, Limpopo is home to many ethnic groups. The envisaged amalgamation aimed at demarcating selected communities of Malamulela and of Vuwani in forming a new municipality. Based on ethnicity this merge was to join two ethnic groups that is the xiTsonga and vhaVenda people into one municipality. However, the Vuwani communities dominated by vhaVenda people refused and rejected this demarcation which resulted in riots.

Territories, boundaries, realistically on the natural ground or through social construction, encourage and discourage connections between community members (Perkmann 2005).

They are hindrances and windows of opportunity that entail different availability in basic needs or resources, and have spatial or non-spatial qualities (Paasi 1990). The theory of territoriality is said to be applicable in understanding demarcation disputes mainly in the northern and eastern parts of Africa. In the Kisanga village of Tanzania, boundary disputes, which can also be called territorial disputes, had manifested because of land tenure insecurities. McCall (2003) further argues that the source of boundary disputes in Kisanga was because of the bad demarcation of boundaries that had ignored existing social boundaries. In many rural areas, most people mainly the old know their own boundaries based on landmarks and ignoring this was the major downfall of demarcation in Tanzania. Delaney and Leitner (1997) argue that territories and geographic scale reflect political spheres. Work from Smith (1992) on boundaries argues that demarcation or drawing of boundaries is manly associates with political struggles.

Arguments have been that demarcations need to be planned properly with caution as territories have a social connection that brings people together in a society (Perkmann 2005, cited in Anderson 1999). According to Collinge (1999, cited in Perkman 2005), territoriality is the way in which spatial political relations are negotiated, where spatial distributions are produced as an outcome, for example, in 'nations', 'regions', and localities. Likewise, 'territoriality' is a conceptual benchmark for making and putting into order social relations. Contextually territories represent politics as a strategic and political action that underlies the evolution of territories (Steinberg 1994:4). It advocates that every visual representation of a border should be expressed as the outcome of social struggles but not intentionally constructed.

Territories are characterised by forms of social representation with its domination being focused within fixed spaces with various number or groups of people (Perkmann 2005). The premise of territories is that they function as places of governance, where institutional organisations generate 
effects that are favourable to certain social vigour on different scales (Ray 1998).

In turn, they provide institutionalised power as a foundation for social actors for whom (the control of) territory becomes a concrete benefit to them. From such a perspective, the issue of the extent of boundaries and their redetermination is very prevalent, because geographic boundaries and the institutional functions that govern them change the social and productive bases of boundaries and also change the resource position boundaries and have an impact on the community as a whole (Perkman 1999). It is clear that the processes of re-determination and delimitation of boundaries have therefore led to social controversy as they can be expected to significantly affect power, resource allocation and life chances of social groups organised at different levels (Perkmann 2005).

\section{Methodology}

The study employed a qualitative approach in collecting its findings. Shank (2002) defines qualitative research as a systematic plan that employs research principles and rules in understanding social realities and people's behaviours. Shank (2002) further argues that scholars in the social sciences school of thought reject the natural sciences principles of research being grounded only on numerical measurements. The social sciences school of thought argues that social world and social realities are embedded in the experiences and meanings that people attach to their daily lives, thus a quantitative approach cannot be used to understand such phenomena. The study aimed at examining the issues of tribalism in Vuwani, as being linked to rejection of the demarcation.

Thus, the use of qualitative approach allowed the research to gain insight into the concept. By using the qualitative approach, the researcher gained an understanding of the issues of tribalism in Vuwani as the underlying effect to rejection and disputing of the demarcation, how participants interpret their experiences, how they construct their worlds and what meanings they attribute to their experiences.

This particular study adopted purposive sampling, as the researcher interviewed people who were affected by the demarcation disputes in Vuwani, and also others who were knowledgeable about the issues raised in the study (Denscombe 2010). Purposive sampling awarded the researcher a rich site with respect to qualitative design principles by targeting Vuwani community members who were active in opposing the demarcation. This form of sampling ensures that data is collected from relevant individuals (Gilbert 2011:25). The purposive sampling technique allowed the researcher to select participants with insight who produced relevant data to the study. Two (2) focus group discussions of 15 members each were conducted of civic union and community members. Focus groups aim to address knowledgeable structures or personnel at the vanguard in challenging re-demarcation in the Vuwani area. Fifteen indepth interviews were conducted. These included the traditional houses affected by demarcation in Vuwani, that is Thovhele Masia, Thovhele Davhana, Thovhele Netshimbupfe, the VhaVenda King and the Vatshonga-Machangani royal house. The representatives of the MDB and local government departments were included in the sample of targeted participants for the interviews. These individuals or traditional houses were selected as they were the most present and dominant in rejecting the then proposed demarcation of Vuwani communities. Thus, the researcher targeted these royal houses to examine the reasons and justifications of rejecting the demarcation and also examining the link of rejections to tribalism. An unstructured interview guide was used to assist the researcher in directing the conversations.

This allowed the researcher the freedom to phrase questions as she wished (see Gilbert 2011:247). Focus group discussion allows respondents an opportunity to express themselves. Driven by the insight of the theoretical framework derived from territorial theory, data was coded and re-occurring themes were highlighted from in-depth interviews and focus groups for analysis. This involved analysis of interviews for common themes, coding and its linking to the theoretical concepts guiding the study (Boeije 2010).

The participants were not forced to participate, and they were informed that they have the right to withdraw from the study at any time if they wished to do so. Pseudonyms were used to refer to the participants to protect their identities. Each participant signed a consent form, which explained that they voluntarily participated in the study. The ethical approval for this study was granted by the Nelson Mandela University in Port Elizabeth.

\section{Discussion of the findings} Demarcation in Vuwani

The majority of Vuwani Vhembe district community members expressed their dissatisfaction with the reasons provided as justification for demarcating their areas. The participants highlighted that the MDB stated that the Thulamulele (Malamulele) communities had requested demarcation from Makhando Municipality as they felt their needs were not catered to and that they were geographically situated far from this municipalities offices. Vuwani participants expressed that if Malamulele communities had applied for demarcation only their communities should be demarcated and not the Vuwani areas who had not applied nor requested for the demarcation. The participants expressed their frustrations with the MDB in including the Vuwani communities in the demarcation instead of demarcating Malamulele communities only. Thus, the participants expressed that this was the main reasons why the disputes erupted. Vuwani communities told that if the MDB and local government had explained properly the reasons why Vuwani communities had to be merged with Malamulele communities in forming this new municipality, things would have taken a positive direction. However, the participants stressed that 
because of the lack of proper communication and consultation and to the reason that they were demarcated without their knowledge, therefore they rejected the reasons brought forth for demarcating their area.

Vuwani communities argued that proper protocol had not been followed mainly the consultations by the MDB. Vuwani community members argue that the MDB was to conduct thorough consultations with both Vuwani and Malamulele community members and submit their proposal of the joint merge of some communities in Vuwani and those in Malamulele to form a new municipality.

The participants described their experience as follows.

One community member stated the following:

'We did not ask for any demarcation, there is no democracy in this country. How can a few people decide on something that would affect all of us, establishment of this new Collins Chabane municipality has not improved anything but have made things worse, How did they decide to join our communities' in Vuwani to this madness is puzzling, should they have demarcated the Malamulele people alone as they had applied for this demarcation. They dragged us into this mess and now we are suffering.' (Participant 4, in-depth interview, Vuwani community member, 2020)

Focus group discussion:

'The government together with that Municipal Demarcation Board were just under pressure by the people of Malamulele, they agreed on the demands of the Malamulele people without stating valid reason and unfortunately, for them they want a war zone. They should have not included us in this madness ... If they wanted to give Malamulele communities their municipality then do so but do not include communities that did not ask for this demarcation nonsense!' (Participant 1 , focus group 1, civil union, 2020)

\section{Reasons of Vuwani residents for refusing inclusion of their communities to the newly established Collins Chabane municipality}

The participants stated a number of reasons why they refuse inclusion of their communities to the Collins Chabane municipality. The major reason being that they had not requested the move. Therefore, they should not be affected by it. The participants also expressed fear of the unknown as they stated that they are not convinced that their needs would be catered for under the Collins Chabane municipality. Thus, they were not willing to gamble their fate, arguing that it is better the devil they know (referring to Makhado municipality) than the one unknown (referring to Collins Chabane municipality). The participants also expressed their fear of being led by xiTsonga people as they reckon that because they had requested the municipality and the fact that the municipality is established in Malamulele geographical setting therefore this gives the xiTonga people more power over the municipality thus fear of negatively being affected as vhaVenda people. This argument creates a sense of tribalism as both tribes fear being controlled by another.
The participants further elaborate fear for their socioeconomical access to aspects such as employment and tender processes, because the municipality is controlled by xiTsonga people. They argue that there is unfairness in job and tender bids allocation thus they refuse to subject themselves under such discrimination. Vuwani community participants further argue that the municipality is new and still have to establish itself in terms of getting efficient staff, find its feet and prove themselves as a municipality in terms of proper management of its budget and provision of services delivery. They state that they cannot wait for such a process thus they are better off with Makhado municipality that is already established and been running for a long period.

Moreover, the participants argue against government and MDB that in their processes they were showing prejudice as their focus was and is on Malamulele by neglecting Vuwani. Thus, this angers Vuwani people arguing it is clear that the MDB has no much respect or care for their communities. This is the reason why they reject the demarcation.

Some of the participants expressed themselves as following in the focus group discussion:

'My sister it better to be with the Makhado municipality, we don't know how things will go with the new municipality and this creates a notion of fear...better the devil we know then the unknown, with that I am saying we are fine with the Makhado municipality as we know how they operate ....' (Participant 5, focus group 1, Vuwani community member, 2020)

'The Collins Chabane municipality is situated in Malamulele, people who are hired and working in the municipality are xiTsonga people. They provide for their own people as they are currently doing, we are sidelined as vhaVenda people, we are not hired, we have no service delivery, no project or tender are awarded to us. They are given to their own people... this is why we want to go back to Makhado and leave these people alone to do their own things...we do not want to be with the Collins Chabane municipality.' (Participant 11, in-depth interview, traditional leader, 2020)

'Why did the Municipal demarcation board reverse the decision they took in 2001? If they can reserve their decision of merging Malamulele to Makhado municipality and give them their own municipality then they have to reverse the decision they took of amalgamating us to Collins Chabane municipality. We will not stop until they do that... this Municipal Demarcation Board and government must treat us all the same... are they trying to say people who deserve respect are only Malamulele people and they don't care about us Vuwani people?' (Participant 7, focus group 2, opposing part/Vuwani community member, 2020)

\section{Tribalism as an underlying catalyst for challenging re-demarcation in Vuwani Vhembe district}

The concept of tribalism has been thrown around in Vuwani, augmenting that the major reasons for challenging demarcation and the establishment of the Collins Chabane Municipality was mainly tribal rivalry, arguing that Malamulele xiTsonga people did not want to be under the leadership of the Venda 
people. These arguments state that Malamulele communities were under development and had the inadequate provision of basic needs when they were under Makhado municipality (vhaVenda leadership), and were argued as being tribal and ethnic rivalries. The participants have argued that this assumption is false and seeks to belittle their argument and objections to the demarcation process.

The participants argue that Limpopo province, mainly Vuwani, is home to different ethnic groups and they have lived peacefully amongst each other. The participants argued against tribalism being the underlying agenda against rejection of Vuwani demarcation stating that the main catalyst to the demarcation disputes is mainly the procedures followed by the MDB. They further indicate that good governance together with constitutional and demarcation act strategies that seek to govern the process of demarcation were not followed thus infringing on people's right resulting in the protests that had been observed.

However, there were participants in the focus group discussions who argued in line with tribalism as they argued that when Malamulele communities were included or merged to Makhado however they (Malamulele communities) disapproved of the merge and challenged it ever since its implementation, mainly because they did not want to be part of a municipality that was headed by Vuwani vhaVenda ethnic. The participants therefore argued that when the Malamulele people had tribalistic tendencies, the government was quiet and has since bowed down to the Malamulele people as they have awarded them the Collins Chabane municipality. Therefore, the participants' argument is that when the Vuwani vhaVenda people followed in the same steps as the xiTsonga people in refusing the demarcation as they also feared and refused being part of a municipality headed by xiTsonga people, they were however labelled as being tribalistic. The participants therefore argued that just like the Malamulele people who had refused the merger stating their reason, they too were not tribalistic because they had the same fears and claims as that of the Malamulele people when they refused and argued against the merge to Vuwani. One of the participants argued that they did not care whether the government together with the MDB chose to belittle their arguments and package them under tribalism, as all they wanted was to be reinstated back to Makhado Municipality:

'The government is very quick to say what is happening here is the bases of tribalism because they want to disregard the effects and the mess they have created here. We are not tribalistic... everyone knows that the Limpopo Province is home to many different tribes...we have the xiTsongas, vhaVenda's, baPedi, etc. and we have lived together over the years peacefully... we have shared ceremonies, have married amongst each other with no problem... and now after so many years, the government says we are tribalistic.' (Participant 12, focus group 2, Vuwani community member, 2020)

'They are the people who introduced that behaviour amongst us... when they decided to favour the xiTsonga people at the expense of other tribes... they created room for tribalism.
Moreover, just to make things clear we are not fighting the xiTsonga people but we are fighting the government and its Municipal Demarcation Board, for coming here and demarcating our land without proper consultations with the people.' (Participant 3, in-depth interview, Vuwani traditional leader 2, 2020)

'This is amazing because if they say we are tribalistic as Vuwani people because we do not want to be part of a municipality that is headed and controlled by xiTsonga people, then they must say the same of the xiTsonga Malamulele people. This is the reason why they also disapproved of their merge to Makhado municipality and requested their own municipality; they did not want to be part of a municipality headed by vhaVenda Vuwani people. When xiTsonga Malamulele people refused to be part of us, the government said nothing about tribalism yet when we do the same; they are quick to say we are tribalistic. You see my sister just as I said there is no equality in this thing, the government and the Municipal Demarcation Board are not fair in their dealings and process of demarcation. They cannot take sides, they need to be neutral at all time... but in this case of our demarcation even a baby can see that they favoured the Malamulele people.' (Participant 6, in-depth interview, ProMakhado Task Team, 2020)

Media reports and some literature around the demarcation disputes of Vuwani highlight it as being a tribal dispute with the vhaVenda people who were refusing to be under the leadership of xiTsonga people. This is because the new Collins Chabane Municipality is situated in Malamulele which is dominated by the xiTsonga people. The findings of the study reveal that Vuwani people are indeed in fear of being under the leadership of the xiTsonga people in terms of provision of basic services, together with employment, tender bids and so forth. However, the Vuwani community argues that the application for demarcation by the Malamulele communities was because of tribalism as they refused being under the leadership of Venda people, because the Makhado Municipality is geographically situated in an area dominated by Venda people. The argument therefore is that it is not only the Venda people who depict signs of tribalism, as Tsonga people also do.

Moloi (2016) warns of a new form pandemic which he argues could have a far worse implication that that of apartheid. Moloi argues that South Africa is a country that is good in dressing a wound rather than healing it. Furthermore, he cautions that if we do not address the wounds of the past we could have a problem at hand. Tribalism seems to be sneaking in as history depicts that each tribe has its own connection and cultural identity that rejects other groups which thus creates tension and leads to conflicts (Moloi 2016:1).

Buhlungu et al. (2007) highlight this by arguing that in provinces where different ethnic groups are found, caution needs to be taken. Mathoho (2013) further argues that in situations where more than one ethnic group is affiliated with one municipality, tribalism comes to play. Because South 
Africa is a diverse country that is home to many ethnic groups, tribalism is a domain influenced highly by the scarcity of resources as people or ethnic groups compete for resources. Race and ethnic groups are at the forefront as people seek to associate with one another in issues of cultural identity and leadership.

On the other hand, the findings of the study reveal that designating the disputes in Vuwani as being purely tribalistic would be unjust. The findings reveal that while there are indeed elements of tribalism within the disputes, however, Limpopo province is home to many ethnic groups who have lived amongst each other for years. The findings further revealed that in as much as tribalism can or is at play, the major underlying factor is lack of good governance principles in terms of transparency and consultation. The issues related to basic service delivery is the catalyst to the disputes as Limpopo province lags behind in the provision of services, with communities competing and scraping for the few resources there are. Managa (2012:2) supports this stating, 'Growing concern has been expressed about the government ability to deliver the public services that its people yearn for and are entitled to'.

\section{Conclusion}

In demarcating South African boundaries, it is essential to take into account the diversity of this country. Thus, good governance principles are to be practised in addressing any misconceptions that can arise. Limpopo province is diverse as it is home to many ethnic groups. Thus, any attempts of demarcation in such provinces need to take into account the history of the country and the damage done by the apartheid government to the country's landscape, and the effects of the segregation and Group Areas Act that divided South African people based on race and ethnicity. Land is a scarce resource in South Africa as much of the land is still under the control of the white minority. Thus, any efforts that seek to threaten land and control it especially in rural land and rural communities in the eyes of rural communities and traditional authority is nothing but an attack and a form of stripping rural people further of their birth right as the apartheid government had done. Thus awareness, education, and imbizo [a gathering, usually called by a traditional leader] are essential in educating one another and ensuring that all stakeholders share the same understanding. Labeling demarcation disputes of Vuwani as being tribalistic is inaccurate as there are other underlying reasons behind them. What presents itself as tribalism is simply a misconception and a sense of favouritism of the MDB and local government. As highlighted in the findings at play in the demarcation of Vuwani is lack of transparency and communication which has led to many misconceptions and feelings of one community is being favoured at the expense of another. The researcher therefore propose that government both local and national and the MDB consult with all stakeholders involved in demarcating Vuwani to find a solution to the ongoing demarcation disputes.

\section{Acknowledgements}

The Vuwani Community who were the participants of this study.

\section{Competing interests}

The author declares that she has no financial or personal relationships that may have inappropriately influenced her in writing this article.

\section{Author's contributions}

T.K. is the sole author of this article.

\section{Ethical considerations}

Ethical clearance to conduct this study was obtained from the Nelson Mandela University, Faculty Postgraduate Studies Committee (FPGSC) of the Faculty of Arts, reference number: H/18/ART/SA-005.

\section{Funding information}

This research received no specific grant from any funding agency in the public, commercial or not-for-profit sectors.

\section{Data availability}

Data sharing is not applicable to this article as no new data were created or analysed in this study.

\section{Disclaimer}

The views and opinions expressed in this article are those of the author and do not necessarily reflect the official policy or position of any affiliated agency of the author.

\section{References}

Anderson, D., 1999, 'The poor are not us, poverty and pastoralism in Eastern Africa', The Journal of Modern African Studies 41(4), 657-658.

Baloyi, E.M., 2018, 'Tribalism: Thorny issue towards reconciliation in South Africa - A practical theological appraisal', HTS Teologiese Studies/Theological Studies 74(2), a4772. https://doi.org/10.4102/hts.v74i2.4772

Bekink, B., 2006, 'Demarcation of new local government boundaries', Doctoral thesis, University of Pretoria.

Boeije, H.R., 2010, The analysis in qualitative research, Sage, London.

Buhlungu, S., Daniel, J., Southhall, R. \& Lutchman, J., 2007, State of the Nation South Africa, HSRC Press, Pretoria.

Bushbuckridge Local Municipality, 2009, Bushbuckridge local municipality water dialogues synthesis report, Bushbuckridge Local Municipality, Bushbuckridge.

Cameron, R.G. (ed.), 1999: The democratisation of South African local government: A tale of three cities, Van Schaik, Pretoria.

Collinge, C., 1999 'Self-organisation of society by scale: a spatial reworking of regulation theory', Environment and Planning Society and Space 17, 557-574.

Delaney, D. \& Leitner, H., 1997, 'The political construction of scale', Political Geography 16(2), 93-97.

Denscombe, M., 2010, The research guide for small-scale social research projects, 4th edn., McGraw-Hill, Berkshire.

Giliomee, H., 2016, The Afrikaners, Tafelberg Publishers Ltd., Paarl.

Gilbert, N., 2011, Researching social life, Sage, London.

Goertz, G. \& Diehl, P.F., 1992, Territorial changes and international conflict, Routledge, New York, NY.

Griggs, R., 1998, 'The security costs of party political boundary demarcations: The case of South Africa', African Security Review 7(2), 22-32. https://doi.org/10. 1080/10246029.1998.9627847 
Hensel, P., 1998, Reliability and validity issues in the ICOW project, University of North Texas, Denton, TX

Kanyane, M., Adonis, C. \& Stephen Rule, S., 2021, 'Vuwani: Understanding the violent community response to municipal boundary re-demarcation', African Security Review 30(1), 102-120. https://doi.org/10.1080/10246029.2020.1845760

Khowa, T., 2020, 'Contesting boundaries: A case of municipal demarcation disputes in Vuwani Vhembe district', viewed n.d., from http://hdl.handle.net/10948/50767

Managa, A., 2012, 'Unfulfilled promises and their consequences: A reflection on local government performance and the critical issue of poor service delivery in South Africa', in Policy Brief: Africa Institute of South Africa 76, p. 2.

Mathoho, M., 2013, Service delivery failures: A threat to local government credibility, viewed 18 May 2017, from http://www.afesis.org.za/Local-Governance-Articles/ service-deliveryfilures-a-threat-to-local-government-credibility-by-malachiamathoho.

McCall, M., 2003, 'Seeking good governance in participatory-GIS: A review of processes and governance dimensions in applying GIS to participatory spatia planning', Habitat International 27(4), 549-573. https://doi.org/10.1016/S01973975(03)00005-5

Moloi, T., 2016, 'Tribalism in new apartheid', News24, viewed 06 July 2016, from https://ondermynende.wordpress.com/2020/01/16/.

Murphy, K.J., 1990, 'Performance pay and top management incentives', Journal of Political Economy 98, 225-264. https://doi.org/10.1086/261677

Nabudere, D.W., 2000, Traditional and modern political systems in contemporary governance in Africa, Africa Study Centre, Uganda.

Narsiah, S. \& Maharaj, B., 1999, 'Borders of dissent in South Africa: The Bushbuckridge Saga', Transformation 40, 36-54.

Niehaus, I., 2005, 'Violence and the boundaries of belonging, comparing two border disputes in the South African lowveld', in V. Bro-Due (ed.), Violence and belonging, the quest for identity in post-colonial Africa, pp. 91-111, Routledge, London.

Nketo, S., 2018, 'Matatiele demarcation in the limelight', News24, viewed n.d., from https://www.news24.com/news24/southafrica/local/east-griqualand-fever/ matatiele-demarcation-in-the-limelight-20180511.

Paasi, A., 1990, 'The rise and fall of Finnish geopolitics', Political Geography Quarterly 9(1), 53-65. https://doi.org/10.1016/0260-9827(90)90006-V

Perkmann, M., 1999, 'Building governance institutions across European borders', Regional Studies 33(7), 657-667.
Perkmann, M., 2005, 'Construction of New Territorial Scales: A Framework and Case Study of the EUREGIO Cross-border Region', Regional Studies 41(2), 253-266.

Perkmann, M., 2005, 'Cross-boarder co-operation as policy entrepreneurship explaning the variable success of European cross-boundaries regions', CSGR working paper no. 166/05, viewed n.d., from https://www.google.com/search?sxsrf=AOaemvJTu no. 166/05, viewed n.d., from https://wwW.google.com/search?sxsrf=AOaemvJTu_ boarder+co-operation+as+policy+entrepreneurship+explaning+the+variable+succ boarder+co-operation+as+policy+entrepreneurship+explaning+the+variable+succ
ess+of+European+cros-boundaries+regions/CSGR+working+paper+No+166/05\&n ess+of+European+cros-boundaries+regions/CSGR+working+paper+No+166/05\&n
$\mathrm{fpr}=1 \&$ sa=X\&ved=2ahUKEwiAopXNjpbOAhXMUMAKHQqgBuYQvgUoAXoECAEQM g\&biw $=1366 \&$ bih $=657 \& d p r=1$.

Pillay, U., 1999, 'Demarcating South Africa's metro areas: A cautionary lesson from the Durban metropolitan area', in R. Cameron (ed.), Democratisation of South African local government: A tale of three cities, pp. 201-223, Van Schaik, Pretoria.

Ray, B., 1998, 'Good governance, administrative reform and socio-economic realities', International Journal of Social Economics 26, 354-369.

Republic of South Africa, 1950, Group Areas Act, Government Printer, Pretoria.

Rugege, S., 2002, 'The institution of traditional leadership and its relation to elected local government', in Seminar Report No. 14, Constitution and Law IV: Colloquium on Local Government Law, pp. 172-176, Konrad Adenauer Stiftung, Johannesburg.

Shank, G., 2002, Qualitative research: A personal skills approach, Merril Prentice Hall, Hoboken, NJ.

Smith, L., 1992, 'Ethical issues in interviewing', Paper presented at the Royal College of Nursing Research Annual Conference, Manchester. https://doi. org/10.1111/j.1365-2648.1992.tb01823.x

Soja, E., 1971, The political organization of space, Association of American Geographers, Commission on College Geography, Washington, DC.

South African Broadcasting Corporation (SABC), 2016, Vuwani villagers urged to object to 'new municipality', viewed 04 March 2019, from http://www.sabc.co.za/news/a/ $7 \mathrm{c} 623600493 \mathrm{e} 664 \mathrm{~b} 9918 \mathrm{dd} 5 \mathrm{~b} 793 \mathrm{dc0bc} /$ ChiefundefinedMasiaundefinedurgesund efinedvillagersundefinedtoundefinedobjectundefinednewmunicipality-20152607.

Steinberg, P., 1994, 'Territory, territoriality and the new industrial geography', Political Geography 13(1), 3-5.

Vasquez, J.A. \& Henehan, M.T., 1999, 'Territorial disputes and the probability of war, 1816-1992', PhD thesis, Department of Political Science, Vanderbilt University, Nashville, Tennessee. 